\title{
Factors affecting the in-vitro development to blastocysts of bovine oocytes matured and fertilized in vitro
}

\author{
Y. Fukui*, L. T. McGowan, R. W. James, P. A. Pugh and H. R. Tervit \\ MAF Technology, Ruakura Agricultural Centre, Private Bag, Hamilton, New Zealand
}

\begin{abstract}
Summary. The effects of media (TCM 199 vs. synthetic oviduct fluid, SOF), sera (foetal calf serum, FCS vs. human serum, $\mathrm{HS})$, gas atmosphere $\left(5 \% \mathrm{CO}_{2}\right.$ in air vs. $5 \% \mathrm{CO}_{2}$, $5 \% \mathrm{O}_{2}$ and $90 \% \mathrm{~N}_{2}$ ) and coculture with bovine oviduct epithelial cells (cells vs. no cells) on the in-vitro development of in-vitro matured and fertilized bovine oocytes were examined. Immature oocytes surrounded with compacted cumulus cells were cultured for $24 \mathrm{~h}$ in TCM 199 supplemented with $10 \% \mathrm{FCS}, 10 \mu \mathrm{g}$ follicle-stimulating hormone $(\mathrm{FSH}) / \mathrm{ml}$ and $10 \mu \mathrm{g}$ luteinizing hormone $(\mathrm{LH}) / \mathrm{ml}, 1 \mu \mathrm{g}$ oestradiol $/ \mathrm{ml}$, and $1 \times 10^{6}$ granulosa cells at $39^{\circ} \mathrm{C}$ under $5 \% \mathrm{CO}_{2}$ in air. In-vitro fertilization was performed with frozen-thawed, heparin-treated $(100 \mu \mathrm{g} / \mathrm{ml}, 15 \mathrm{~min})$ spermatozoa from 2 bulls. Oocytes were incubated with $2.5 \times 10^{6}$ spermatozoa/ml for $24 \mathrm{~h}$ and then cultured in one of 16 treatments for 7 days. Cleavage (2-8-cell) and development to blastocysts were recorded on Days 2 and 7, respectively, after the start of culture.

SOF was superior to TCM 199 for cleavage $(P<0.01)$, development to blastocysts $(P<0.001)$ and for proportion of cultured ova resulting in blastocysts with at least 60 or at least 100 nuclei $(P<0.001)$. FCS was superior to HS for development to blastocysts $(P<0.001)$ and $5 \%$ oxygen was superior to air for the proportion of ova reaching at least 60 cells $(P<0.01)$. For cleavage and development to blastocysts, there was an interaction between serum and cells $(P<0.01)$. In the presence of cells, ova preferred FCS; in their absence, serum had little effect. A third-order interaction between medium, cells and gases for percentage of ova developing to blastocysts $(P<0.001)$ and percentage developing to at least 60 nuclei $(P<0.01)$ showed that, without cells, $5 \%$ oxygen was advantageous in both media. With cells, gas had little effect on development in SOF, but ova in TCM 199 developed most readily in air. The highest incidence of development to blastocysts in TCM 199 (22\% of ova cultured) occurred when ova were cultured with cells, FCS and air. The best development in SOF occurred with cells, FCS and either air $(32 \%)$ or $5 \%$ oxygen $(27 \%)$; or no cells, $5 \%$ oxygen and either FCS (31\%) or HS (26\%).

The results show that the choice of culture conditions has a marked effect on the development of in-vitro matured and fertilized cattle oocytes. We choose to culture in SOF $+5 \%$ oxygen + FCS or HS routinely as this system is easy to set up, since it does not involve coculture and the effect of culture additives is not confounded by effects on cells and embryos.
\end{abstract}

Keywords: cattle; oocyte; in-vitro fertilization; embryonic development; coculture

\section{Introduction}

In recent years, the success of oocyte in-vitro maturation and fertilization in farm animals has been greatly improved, pregnancies or offspring being obtained after culture of oocytes in vivo or in vitro

* Present address: Laboratory of Animal Genetics and Reproduction, Obihiro University of Agriculture and Veterinary Medicine, Obihiro 080, Japan. 
and transfer of embryos to recipient animals (sheep: Cheng et al., 1986; Crozet et al., 1987; pigs: Cheng et al., 1986; Yoshida, 1987; cattle: Hanada et al., 1986; Goto et al., 1988; Lu et al., 1988; Fukuda et al., 1990; Kajihara et al., 1990). However, the percentage of oocytes reaching the blastocyst stage in a completely in-vitro system (i.e. maturation, fertilization and culture in vitro) is still low, at 6-20\% (Fukui \& Ono, 1988; Goto et al., 1988, 1989; Lu et al., 1988; Fukui \& Ono, 1989; Fukuda et al., 1990). Some improvements in oocyte maturation systems (Fukui \& Ono, 1989; Sanbuissho \& Threlfall, 1989) and methods for sperm preparation (Parrish et al., 1986, 1988; Niwa \& Ohgoda, 1988; Handrow et al., 1989) have been made, but the development of simple and reliable culture systems to support embryonic deyelopment beyond the morula stage after in-vitro maturation and fertilization of oocytes is still required.

Many systems for culturing preimplantation sheep and cattle embryos have been reported. They include coculturing embryos with somatic cells (trophoblastic vesicles: Camous et al., 1984; Heyman \& Menezo, 1987; oviduct epithelial cells: Gandolfi \& Moor, 1987; Lu et al., 1988; Fukui \& Ono, 1988; cumulus cells: Goto et al., 1988, 1989; Fukuda et al., 1990), supplementation of media with human serum (Walker et al., 1986, 1988; McLaughlin et al., 1989) and culture under low oxygen concentrations (Tervit et al., 1972; Walker et al., 1986, 1988; McLaughlin et al., 1989). Since Gandolfi \& Moor (1987) showed that one-cell sheep embryos developed to beyond the morula stage when cocultured with ovine oviduct epithelial cells, most studies have used a coculture system. It has been suggested that cultured sheep and cattle embryos require contact with somatic cells (Allen \& Wright, 1984) or exposure to mitogenic factors secreted by the cells (Gandolfi \& Moor 1987; Heyman \& Menezo, 1987). However, other workers (Tervit et al., 1972; Tervit \& Rowson, 1974; Walker et al., 1986, 1988; McLaughlin et al., 1989) have reported that sheep and cattle embryos develop readily in vitro without somatic cell support if cultured in the defined medium synthetic oviduct fluid (SOF), under a gas atmosphere of $5 \% \mathrm{CO}_{2}, 5 \% \mathrm{O}_{2}$ and $90 \% \mathrm{~N}_{2}$. Walker et al. (1986) and McLaughlin et al. (1989) have also demonstrated that a high proportion of one-cell sheep and cattle embryos develop to blastocysts when cultured in SOF supplemented with $10-20 \%$ human serum.

The present trial investigated the effect of some of these culture variables on the development of in-vitro matured and fertilized bovine ova in vitro.

\section{Materials and Methods}

In-vitro maturation. Ovaries were obtained from cows and heifers killed at a local abattoir and were transported in saline $(9 \mathrm{~g} \mathrm{NaCl} / \mathrm{l})$ at $30-35^{\circ} \mathrm{C}$ to the laboratory within $1-2 \mathrm{~h}$ of slaughter. Cumulus-oocyte complexes were aspirated from follicles of 2-5 mm diameter using suction from a vacuum pump directed through an 18 -gauge needle, connected to a $10-\mathrm{ml}$ test tube containing aspiration medium (TCM199 (pH 7.4; Earle's salt with L-glutamine and without sodium bicarbonate; Gibco Laboratories, Inc., Grand Island, NY, USA) supplemented with $0.4 \%$ (w/v) bovine serum albumin (BSA; fatty-acid free, Fraction V; Sigma Chemical Co., St Louis, MO, USA), $20 \mathrm{~mm}$ Hepes, $4 \mathrm{~mm}-\mathrm{NaHCO}_{3}$ and $50 \mu \mathrm{g}$ heparin/ml (H3125, Grade I; Sigma)). Oocytes with an unexpanded cumulus oophorus and evenly granulated cytoplasm were cultured in a 12-well plate (Linbro; Flow Laboratories, Inc., McLean, VA, USA: 20-30 oocytes/well) containing $1 \mathrm{ml} \mathrm{TCM} 199(\mathrm{pH} 7 \cdot 4)$ supplemented with $10 \%$ (v/v) heat-inactivated $(56 \mathrm{C}, 30 \mathrm{~min})$ foetal calf serum (FCS) and $25 \mathrm{~mm}-\mathrm{NaHCO}_{3}$. The medium was also supplemented with $10 \mu \mathrm{g}$ ovine folliclestimulating hormone (FSH)/ml (Ovagen, Immunochemical Products Ltd, Auckland, NZ), $10 \mu \mathrm{g}$ ovine luteinizing hormone (LH)/ml (Immunochemical Products), $1 \mu \mathrm{g}$ oestradiol $/ \mathrm{ml}$ (Sigma) and with $1 \times 10^{6} \mathrm{granulosa} \mathrm{cells} / \mathrm{ml}$. Granulosa cells were collected by aspiration of antral follicles $>5 \mathrm{~mm}$ in diameter and then washed (centrifuged at $500 \mathrm{~g}$ for $5 \mathrm{~min}$ ) twice with the aspiration medium. Oocytes were statically cultured for $24 \mathrm{~h}$ at $39^{\circ} \mathrm{C}$ under $5 \% \mathrm{CO}_{2}$ in air and $95 \%$ humidity. At the end of culture, some oocytes were fixed, stained (Fukui et al., 1983) and examined for the presence of the second metaphase plate and polar body.

Sperm preparation. Four $0.25-\mathrm{ml}$ frozen straws of semen from 2 bulls were thawed at $37^{\circ} \mathrm{C}$, pooled and prepared for sperm capacitation. The thawed semen $(0.2 \mathrm{ml})$ was layered under $1 \mathrm{ml}$ modified Tyrode's calcium-free capacitation medium ( $\mathrm{pH} \mathrm{7.4;} \mathrm{Lu} \mathrm{et} \mathrm{al.,} \mathrm{1988)} \mathrm{in} \mathrm{conical} \mathrm{tubes} \mathrm{and} \mathrm{allowed} \mathrm{to} \mathrm{swim-up} \mathrm{during} \mathrm{incubation} \mathrm{for} 1 \mathrm{~h}$ at $39 \mathrm{C}$ in $5 \% \mathrm{CO}_{2}$ in air. After incubation, the top $0.8 \mathrm{ml}$ of medium from each tube was pooled and the spermatozoa were washed twice $(500 \mathrm{~g}, 10 \mathrm{~min})$ with the capacitation medium. The final pellet of semen was resuspended to $50 \times 10^{6}$ spermatozoa $/ \mathrm{ml}$ containing $100 \mu \mathrm{g}$ heparin $/ \mathrm{ml}$ and incubated for $15 \mathrm{~min}$ at $39^{\circ} \mathrm{C}$ in $5 \% \mathrm{CO}_{2}$ in air. After incubation, the sperm suspension was diluted $1: 1(\mathrm{v} / \mathrm{v})$ with the capacitation medium. 
In-vitro fertilization. The oocytes matured in vitro were washed three times with a modified Tyrode's washing medium ( $\mathrm{pH} 7 \cdot 4 ; \mathrm{Lu}$ et al., 1987) containing $2 \mathrm{~mm}-\mathrm{CaCl}_{2}$ and $2 \mathrm{mM}-\mathrm{NaHCO}_{3}$ and the surrounding cumulus cells were partly removed by gentle pipetting. Samples $(2 \mu \mathrm{l})$ of washing medium containing 5 oocytes were placed into $43-\mu \mathrm{l}$ drops of a modified fertilization medium ( $\mathrm{pH} 7.8$; Lu et al., 1987) under mineral oil (Squibb E. R. \& Sons, Inc., Princeton, NJ, USA). A 5- $\mu$ l sample of the heparin-treated spermatozoa was then added to the oocytes (final sperm concentration, $2.5 \times 10^{6} \mathrm{cells} / \mathrm{ml}$ ). Oocytes and spermatozoa were incubated together for $20-24 \mathrm{~h}$ at $39^{\circ} \mathrm{C}$ under $5 \%$ $\mathrm{CO}_{2}$ in air. After incubation, some oocytes were fixed, stained and examined for evidence of normal (2 pronuclei and a sperm tail) and abnormal (polyspermic) fertilization.

In-vitro culture. The oocytes inseminated in vitro were pooled and then randomized into one of 16 treatment groups (TCM199 vs. SOF; FCS vs. human serum (HS); $5 \% \mathrm{CO}_{2}$ in air vs. $5 \% \mathrm{CO}_{2}, 5 \% \mathrm{O}_{2}$ and $90 \% \mathrm{~N}_{2}$; bovine oviduct epithelial cells vs. no cells). Both TCM199 and SOF were supplemented with 10\% (v/v) FCS or HS and the oviduct epithelial cells were prepared 2 days before the start of culture using the method described by Fukui \& Ono (1989). All cultures were incubated for 7 days at $39^{\circ} \mathrm{C}$ in 24 -well plates (Nunclon, Inter Med, Kamstrup, Denmark), each well containing $0.5 \mathrm{ml}$ medium and 10-15 oocytes. The gas atmospheres were maintained by continuous flow of humidified gases. On Day 2 of culture, ova were examined for cleavage to 2-8 cells and at the end of culture for development to blastocysts. The number of cells in some blastocysts and expanded blastocysts was determined using the method of Ushijima et al. (1988).

The incidence of parthenogenetic cleavage in oocytes incubated with killed spermatozoa was determined by culturing in TCM $199+\mathrm{FCS}+$ oviduct epithelial cells under $5 \% \mathrm{CO}_{2}$ in air, or in SOF + $\mathrm{HS}$ under $5 \% \mathrm{CO}_{2}, 5 \% \mathrm{O}_{2}$ and $90 \% \mathrm{~N}_{2}$.

Statistical analysis. The proportions of oocytes cleaving, developing to blastocysts, and developing to blastocysts with at least 60 or at least 100 nuclei (the former group includes all the blastocysts in the latter group) were analysed by multiple regression analysis following logit transformation. The numbers of nuclei in blastocysts were analysed by analysis of variance using log-transformed data.

\section{Results}

The proportion of oocytes reaching metaphase II by the end of in-vitro maturation was $82 \cdot 9 \pm 3 \cdot 1 \%$ (s.e.m., $n=152,7$ replicates). Fertilization rate was $85 \cdot 6 \pm 2 \cdot 6 \%(n=181,12$ replicates) and included $13 \cdot 6 \pm 2 \cdot 8 \%$ polyspermic fertilization. The frequency of normal fertilization $(2$ pronuclei and a sperm tail) was $74.0 \pm 3 \cdot 3 \%$. The incidence of parthenogenetic cleavage in TCM 199 and SOF was $0 \cdot 8 \pm 0.8 \%$ and $3 \cdot 2 \pm 1 \cdot 6 \%$, respectively (122 and 125 eggs, respectively; 6 replicates).

Overall, SOF was superior to TCM199 for both cleavage $(P<0.01)$ and development to blastocysts $(P<0.001)$ (Table 1); FCS was superior to HS for development to blastocysts $(P<0.001)$. There was an interaction between serum and oviduct epithelial cells for both cleavage and development to blastocysts $(P<0.01)$. In the presence of cells, fewer ova cleaved and developed to blastocysts in HS than in FCS ( 55 vs. 64,10 vs. $21 \%$, respectively; back-transformed data). In the absence of cells, serum had little effect on either parameter (64 vs. $60,13 \mathrm{vs.} 14 \%$, respectively). There was a third-order interaction $(P<0.001)$ between medium, oviduct epithelial cells and gases for percentage of ova developing to blastocysts (Table 2). The gas containing $5 \%$ oxygen was advantageous when ova were cultured in SOF or TCM 199 without oviduct epithelial cells. In the presence of cells, gas had little effect on development in SOF, but ova in TCM199 developed most readily in air. This interaction was not observed for proportions of ova cleaving. However, for this end-point, an interaction between gases and oviduct epithelial cells $(P<0.05)$ showed that air was advantageous for cleavage when cells were present (63 vs. $56 \%$ cleaving, respectively), but, in the absence of cells, gas had little effect (62 vs. 63\%, respectively).

Since $74 \%$ of ova were normally fertilized, it is possible to calculate for each treatment the percentage of embryos developing to blastocysts. This ranged from $2 \cdot 1$ to $42 \cdot 2 \%$, the best development occurring in SOF + FCS + oviduct epithelial cells + air $(42 \cdot 2 \%)$ and SOF $+\mathrm{FCS}+5 \% \mathrm{O}_{2}$ $(41 \cdot 1 \%)$.

An interaction $(P<0.01)$ was observed between medium and gases for numbers of nuclei/ blastocyst (Table 3). Blastocysts developing in TCM199 had most nuclei when cultured in air and those in SOF had most nuclei when cultured in $5 \%$ oxygen. Factors affecting the proportion of 
Table 1. Effects of medium, serum, gases and the presence or absence of bovine oviduct epithelial cells $(\mathrm{BOEC})$ on in-vitro cleavage and development to blastocysts of bovine oocytes matured and fertilized in vitro

\begin{tabular}{|c|c|c|c|c|c|c|}
\hline \multirow[b]{2}{*}{ Gas } & \multirow[b]{2}{*}{ Medium* } & \multirow[b]{2}{*}{ Serum $\dagger$} & \multirow[b]{2}{*}{ Cells } & \multirow[b]{2}{*}{$\begin{array}{l}\text { No. of ova } \\
\text { cultured }+\end{array}$} & \multicolumn{2}{|c|}{$\%$ ova (mean \pm s.e.m.) } \\
\hline & & & & & Cleaved & $\begin{array}{c}\text { Developed to } \\
\text { blastocysts }\end{array}$ \\
\hline \multirow[t]{8}{*}{$5 \% \mathrm{CO}_{2}$ in air } & 199 & FCS & \multirow[t]{2}{*}{ BOEC } & $122(11)$ & $66 \cdot 5 \pm 4 \cdot 2$ & $21.9 \pm 3.8$ \\
\hline & 199 & FCS & & 121 (11) & $53.4 \pm 4.5$ & $3.5 \pm 1.7$ \\
\hline & 199 & HS & \multirow[t]{2}{*}{ BOEC } & $130(12)$ & $55.7 \pm 4.4$ & $11.3 \pm 2.8$ \\
\hline & 199 & HS & & $127(12)$ & $61 \cdot 8 \pm 4 \cdot 3$ & $1 \cdot 5 \pm 1 \cdot 1$ \\
\hline & SOF & FCS & \multirow[t]{2}{*}{ BOEC } & $122(10)$ & $67 \cdot 8 \pm 4 \cdot 2$ & $31.9 \pm 4.2$ \\
\hline & SOF & FCS & & $122(11)$ & $62.3 \pm 4.4$ & $11 \cdot 1 \pm 2.9$ \\
\hline & SOF & HS & \multirow[t]{2}{*}{ BOEC } & $126(12)$ & $62 \cdot 4 \pm 4 \cdot 3$ & $14 \cdot 2 \pm 3 \cdot 1$ \\
\hline & SOF & HS & & $127(12)$ & $66 \cdot 4 \pm 4 \cdot 2$ & $10 \cdot 1 \pm 2.6$ \\
\hline \multirow{8}{*}{$\begin{array}{c}5 \% \mathrm{CO}_{2}, 5 \% \mathrm{O}_{2} \\
\text { and } 90 \% \mathrm{~N}_{2}\end{array}$} & 199 & FCS & \multirow[t]{2}{*}{ BOEC } & $125(11)$ & $57 \cdot 5 \pm 4 \cdot 4$ & $2 \cdot 5 \pm 1.4$ \\
\hline & 199 & FCS & & $119(12)$ & $60 \cdot 7 \pm 4.6$ & $9.7 \pm 2.8$ \\
\hline & 199 & HS & \multirow[t]{2}{*}{ BOEC } & $127(12)$ & $44.9 \pm 4.4$ & $1 \cdot 5 \pm 1 \cdot 1$ \\
\hline & 199 & HS & & $123(12)$ & $62 \cdot 8 \pm 4.4$ & $15.9 \pm 3.3$ \\
\hline & SOF & FCS & \multirow[t]{2}{*}{ BOEC } & $114(10)$ & $64 \cdot 1 \pm 4 \cdot 4$ & $26 \cdot 5 \pm 4 \cdot 2$ \\
\hline & SOF & FCS & & $121(11)$ & $62.8 \pm 4.4$ & $31 \cdot 2 \pm 4 \cdot 2$ \\
\hline & SOF & HS & \multirow[t]{2}{*}{ BOEC } & $124(12)$ & $57.9 \pm 4.4$ & $13.5 \pm 3.0$ \\
\hline & SOF & HS & & $124(12)$ & $63 \cdot 3 \pm 4 \cdot 2$ & $26.0 \pm 3.9$ \\
\hline
\end{tabular}

*TCM 199 or synthetic oviduct fluid (SOF).

†Foetal calf serum (FCS) or human serum (HS).

${ }_{+}$No. of replicates in parentheses.

Table 2. Effect of medium, bovine oviduct epithelial cells (BOEC) and gases on percentage* of ova developing to blastocysts

\begin{tabular}{lrrrrr}
\hline \multirow{2}{*}{ Gas } & \multicolumn{2}{c}{ TCM199 } & & \multicolumn{2}{c}{$\begin{array}{c}\text { Synthetic } \\
\text { oviduct fluid }\end{array}$} \\
\cline { 2 - 3 } & BOEC & No. cells & & BOEC & No. cells \\
\hline $5 \% \mathrm{CO}_{2}$ in air & $16 \cdot 3$ & $2 \cdot 5$ & $22 \cdot 6$ & $10 \cdot 5$ \\
$5 \% \mathrm{CO}_{2}, 5 \% \mathrm{O}_{2}$ and $90 \% \mathrm{~N}_{2}$ & 2.0 & 12.9 & & $19 \cdot 6$ & 28.5 \\
\hline
\end{tabular}

*Back-transformed data.

ova developing to blastocysts with $\geqslant 60$ or $\geqslant 100$ nuclei were the same as those affecting the development to total number of blastocysts (i.e. SOF was superior to TCM199 $(P<0.001)$ for development to $\geqslant 60$ and $\geqslant 100$ cells, and $5 \%$ oxygen was superior to air $(P<0.01)$ for development to $\geqslant 60$ cells; there was also a third-order interaction $(P<0.01)$ between medium, oviduct epithelial cells and gases for development to blastocysts with $\geqslant 60$ or $\geqslant 100$ nuclei).

\section{Discussion}

The present study shows that the proportion of ova developing to blastocysts is markedly affected by the combination of culture conditions used. This may explain some of the variation between laboratories in culture success rates. Under certain conditions, ova develop readily to blastocysts, with or without oviduct epithelial cell coculture, in SOF or TCM 199, foetal calf serum or human serum and 5 or $20 \%$ oxygen. 
Table 3. Number of nuclei in blastocysts after in-vitro culture of bovine oocytes matured and fertilized in vitro

\begin{tabular}{|c|c|c|c|c|c|c|c|}
\hline \multirow[b]{2}{*}{ Gas } & \multirow[b]{2}{*}{ Medium* } & \multirow[b]{2}{*}{ Serumt } & \multirow[b]{2}{*}{ Cells } & \multirow{2}{*}{$\begin{array}{l}\text { No. of } \\
\text { blastocysts } \\
\text { examined }\end{array}$} & \multirow{2}{*}{$\begin{array}{c}\text { Mean ( } \pm \text { s.e.m.) } \\
\text { no. nuclei per } \\
\text { blastocyst }\end{array}$} & \multicolumn{2}{|c|}{$\begin{array}{l}\% \text { cultured ova producing } \\
\text { blastocysts with }\end{array}$} \\
\hline & & & & & & $\geqslant 60$ nuclei & $\geqslant 100$ nuclei \\
\hline \multirow[t]{8}{*}{$5 \% \mathrm{CO}_{2}$ in air } & 199 & FCS & BOEC & 16 & $114 \pm 12 \cdot 5$ & $11 \cdot 6$ & $7 \cdot 7$ \\
\hline & 199 & FCS & & 0 & - & $0 \cdot 0$ & $0 \cdot 0$ \\
\hline & 199 & HS & BOEC & 6 & $122 \pm 10 \cdot 6$ & $5 \cdot 1$ & $4 \cdot 2$ \\
\hline & 199 & HS & & 1 & 84 & 0.8 & 0.0 \\
\hline & SOF & FCS & BOEC & 27 & $80 \pm 8.8$ & $15 \cdot 3$ & $5 \cdot 3$ \\
\hline & SOF & FCS & & 11 & $83 \pm 11.5$ & $6 \cdot 2$ & $3 \cdot 5$ \\
\hline & SOF & HS & BOEC & 16 & $86 \pm 6 \cdot 3$ & $11 \cdot 5$ & $4 \cdot 0$ \\
\hline & SOF & HS & & 9 & $68 \pm 9 \cdot 6$ & $4 \cdot 0$ & 1.6 \\
\hline \multirow{8}{*}{$\begin{array}{l}5 \% \mathrm{CO}_{2}, 5 \% \mathrm{O}_{2} \\
\text { and } 90 \% \mathrm{~N}_{2}\end{array}$} & 199 & FCS & BOEC & 1 & 83 & 0.9 & 0.0 \\
\hline & 199 & FCS & & 9 & $66 \pm 7.5$ & $4 \cdot 6$ & 0.9 \\
\hline & 199 & HS & BOEC & 1 & 100 & $0 \cdot 8$ & 0.8 \\
\hline & 199 & HS & & 13 & $82 \pm 10 \cdot 6$ & $8 \cdot 7$ & $2 \cdot 6$ \\
\hline & SOF & FCS & BOEC & 22 & $92 \pm 8 \cdot 1$ & $17 \cdot 4$ & $7 \cdot 7$ \\
\hline & SOF & FCS & & 29 & $93 \pm 8.4$ & $20 \cdot 1$ & $9 \cdot 1$ \\
\hline & SOF & $\mathrm{HS}$ & BOEC & 13 & $93 \pm 7.8$ & $9 \cdot 3$ & $6 \cdot 7$ \\
\hline & SOF & HS & & 26 & $84 \pm 5 \cdot 5$ & $17 \cdot 5$ & $7 \cdot 4$ \\
\hline
\end{tabular}

*TCMI99 or synthetic oviduct fluid (SOF).

†Foetal calf serum (FCS) or human serum (HS).

To our knowledge, this is the first report demonstrating that somatic cell support is not required for in-vitro development to the blastocyst stage of bovine oocytes matured and fertilized in vitro. It is in contrast to the results of Nakao \& Nakatsuji (1990), who observed that, even when the medium and gas phase were altered, coculture remained the prerequisite for a high rate of development. There have been many reports of the embryotrophic effect of cocultured cells; Gandolfi \& Moor (1987) unequivocally demonstrated that oviduct cells can manufacture an environment in vitro that is compatible with normal embryo development. The exact role of cocultured somatic cells is, however, still not clear. Some suggest that they act through physical contact of the cells and embryos (Allen \& Wright, 1984) and that conditioned medium will not support development (Allen \& Wright, 1984; Rexroad \& Powell, 1988). Others have shown that conditioned medium will support development (Heyman \& Menezo, 1987; Eyestone \& First, 1989; Wang et al., 1990) and that the cells secrete mitogenic factors, the physiological role of which has yet to be determined (Heyman \& Menezo, 1987; Gandolfi et al., 1989). Bavister (1988) proposed that the cells may secrete beneficial factors and/or remove detrimental factors. In particular, he proposed that one action of the cells could be to lower the oxygen tension in the immediate vicinity of the embryo. The present trial was not designed to clarify the role of somatic cells. However, the interaction between medium, oviduct epithelial cells and gases, while confirming our earlier observation that, in the absence of somatic cells, ova develop most readily when the gas contains less oxygen than air (Tervit et al., 1972; Thompson et al., 1990), also shows that ova in TCM199 develop readily in $20 \%$ oxygen (air) when cells are present. This suggests that the cells mitigate the harmful effects of high oxygen concentrations (Pabon et al., 1989; Thompson et al., 1990), possibly by reducing the oxygen concentration in the medium or by producing antioxidants. The poor development of ova in TCM199 + oviduct epithelial cells $+5 \%$ oxygen may be due to impaired somatic cell function at this oxygen concentration or to the combination of cells and low oxygen leading to near-anaerobic conditions. We have no explanation why ova developed readily in SOF + oviduct epithelial cells $+5 \%$ oxygen, but we noted that the cells in this treatment rapidly degenerated during culture. Clearly, further studies are warranted to clarify the function of cocultured somatic cells and to assess the viability of blastocysts produced without somatic cell support. 
The overall superiority of SOF over TCM199 was of interest since, although workers in Australia and New Zealand prefer SOF (Walker et al., 1986, 1988; McLaughlin et al., 1989; Thompson et al., 1990), others have found little advantage of this medium over media such as Ham's F-10 and B2 (Heyman \& Menezo, 1987; Wright \& O'Fallon, 1987). We have no explanation as to why SOF was superior in this study, except that, in our experience, media based on the ionic composition of oviduct fluid, such as SOF and Human Tubal Fluid (Quinn et al., 1984), readily support development of mammalian embryos in vitro.

The present study shows that the effectiveness of foetal calf and human serum as protein supplements depends on the culture conditions used. Foetal calf serum was superior when oviduct epithelial cells were present, perhaps because it has factors which promote the development of the cells or, as described by Heyman \& Menezo (1987), because it effectively potentiates the embryotrophic signal. Walker et al. (1986) showed that human serum was superior to bovine serum albumin for culture of sheep embryos and they and others (McLaughlin et al., 1989) regularly and successfully culture sheep and cattle embryos in SOF supplemented with $20 \%$ human serum and with no somatic cell support. In the present trial, human serum was not superior to foetal calf serum when oviduct epithelial cells were absent, suggesting that human serum may not have an advantage for cattle embryos. However, in the present trial, results may have been affected by the use of $10 \%$, rather than $20 \%$, serum.

In conclusion, the present study shows that the success of a particular culture system depends on the correct combination of a number of parameters. In our laboratory, we prefer to culture ova without somatic cell support in SOF, $5 \%$ oxygen and either foetal calf or human serum, as the system is easier to establish than a coculture system and the effects of culture additives are not confounded by effects on both cells and embryos.

Y. Fukui has been supported by a grant from the MAF Technology Senior Fellowship of New Zealand. We thank Mr D. Duganzich for the statistical analysis, Dr J. G. E. Thompson for discussion and comments, and Ambreed, Hamilton, New Zealand for the generous supply of semen.

\section{References}

Allen, R.L. \& Wright, R.W. (1984) In vitro development of porcine embryos in co-culture with endometrial cell monolayers or culture supernatants. J. Anim. Sci. 59, 1657-1661.

Bavister, B.D. (1988) Role of oviductal secretions in embryonic growth in vivo or in vitro. Theriogenology 29, 143-154.

Camous, S., Heyman, Y., Meziou, W. \& Menezo, Y. (1984) Cleavage beyond the block stage and survival after transfer of early bovine embryos cultured with trophoblastic vesicles. J. Reprod. Fert. 72, 479-485

Cheng, W.T.K., Moor, R.M. \& Polge, C. (1986) In vitro fertilization of pig and sheep oocytes matured in vivo and in vitro. Theriogenology 25, 146, Abstr.

Crozet, N., Huneau, D., De Smedt, V., Theron, M.C., Szollosi, D., Torres, S. \& Sevellec, C. (1987) In vitro fertilization with normal development in the sheep. Gamete Res. 16, 159-170.

Eyestone, W.H. \& First, N.L. (1989) Co-culture of early cattle embryos to the blastocyst stage with oviductal tissue or in conditioned medium. J. Reprod. Fert. 85, 715-720.

Fukuda, Y., Ichikawa, M., Naito, K. \& Toyoda, Y. (1990) Birth of normal calves resulting from bovine oocytes matured, fertilized, and cultured with cumulus cells in vitro up to the blastocyst stage. Biol. Reprod. 42, 114-119.

Fukui, Y. \& Ono, H. (1988) In vitro development to blastocysts of in vitro matured and fertilized bovine oocytes. Vet. Rec. 122, 282.

Fukui, Y. \& Ono, H. (1989) Effects of sera, hormones, and granulosa cells added to culture medium for in-vitro maturation, fertilization, cleavage and development of bovine oocytes. J. Reprod. Fert. 86, 501-506.

Fukui, Y., Fukushima, M. \& Ono, H. (1983) Fertilization in vitro of bovine oocytes after various sperm procedures. Theriogenology 20, 651-660.

Gandolfi, F. \& Moor, R.M. (1987) Stimulation of early embryonic development in sheep by co-culture with oviduct epithelial cells. J. Reprod. Fert. 81, 23-28.

Gandolfi, F., Brevini, T.A.L. \& Moor, R.M. (1989) Effect of oviductal environment on embryonic development. $J$. Reprod. Fert., Suppl. 38, 107-115.

Goto, K., Kajihara, Y., Kosaka, S., Koba, M., Nakanishi, Y. \& Ogawa, K. (1988) Pregnancies after co-culture of cumulus cells with bovine embryos derived from in-vitro fertilization of in-vitro matured follicular oocytes. J. Reprod. Fert. 83, 753-758. 
Goto, K., Koba, M., Takuma, Y., Nakanishi, Y. \& Ogawa, K. (1989) Co-culture of bovine embryos with cumulus cells. Asian-Aust. J. Anim. Sci. 2, 595-598.

Hanada, A., Shioya, Y. \& Suzuki, T. (1986) Birth of calves after transfer of bovine embryos produced by in-vitro fertilization of in vitro matured oocytes. Proc. 78th meeting Jpn. Soc. Zootech. Sci., p. 18, Abstr. (In Japanese.)

Handrow, R.R., First, N.L. \& Parrish, J.J. (1989) Calcium requirement and increased association with bovine sperm during capacitation by heparin. J. exp. Zool. 252, 174-182.

Heyman, Y. \& Menezo, Y. (1987) Interaction of trophoblastic vesicles with bovine embryos developing in vitro. In The Mammalian Preimplantation Embryo, pp. 175-191. Ed. B. D. Bavister. Plenum Press, New York.

Kajihara, Y., Kometani, N., Kobayashi, S., Shitanaka, Y., Koshiba, Y., Hishyama, K., Shiraiwa, K. \& Goto, K. (1990) Pregnancy rates and births after co-culture of cumulus cells with bovine embryos derived from in vitro fertilization of in vitro matured follicular oocytes. Theriogenology 32, 264, Abstr.

Lu, K.H., Gordon, I., Gallagher, M. \& McGovern, H. (1987) Pregnancy established in cattle by transfer of embryos derived from in vitro fertilization of oocytes matured in vitro. Vet. Rec. 121, 259-260.

Lu, K.H., Gordon, I., Chen, H.B., Gallagher, M. \& McGovern, H. (1988) Birth of twins after transfer of cattle embryos produced by in vitro techniques. Vet. Rec. 122, 539-540.

McLaughlin, K.J., Ashman, R.J., McLean, D.M., Stevens, G., Bartsch, B.D. \& Seamark, R.F. (1989) Viability of one cell bovine embryos cultured in synthetic oviduct fluid medium. Proc. Aust. Soc. Reprod. Biol. 21, 36, Abstr.

Nakao, H. \& Nakatsuji, N. (1990) Effects of co-culture, medium components and gas phase on in vitro culture of in vitro matured and in vitro fertilized bovine embryos. Theriogenology 33, 591-600.

Niwa, K. \& Ohgoda, O. (1988) Synergistic effect of caffeine and heparin on in vitro fertilization of cattle oocytes matured in culture. Theriogenology 30, 733-741.

Pabon, J.E., Jr, Findley, W.E. \& Gibbons, W.E. (1989) The toxic effect of short exposures to the atmosphere oxygen concentration on early mouse embryonic development. Fert. Steril. 51, 896-900.

Parrish, J.J., Susko-Parrish, J.L., Leibfried-Rutledge, M.L., Critser, F.S., Eyestone, W.H. \& First, N.L. (1986) Bovine in vitro fertilization with frozen-thawed semen. Theriogenology 25, 591-600.

Parrish, J.J., Susko-Parrish, J.L., Winer, M.A. \& First, N.L. (1988) Capacitation of bovine sperm by heparin. Biol. Reprod. 38, 1171-1180.
Quinn, P., Warnes, G.M., Walker, S.K. \& Seamark, R.F. (1984) Culture of preimplantation sheep and goat embryos. In Reproduction in Sheep, pp. 289-290. Eds D. R. Lindsay \& D. T. Pearce. Australian Academy of Science and Australian Wool Corporation, Canberra.

Rexroad, C.E. \& Powell, A.M. (1988) Co-culture of ovine eggs with oviductal cells and trophoblastic vesicles. Theriogenology 29, 387-397.

Sanbuissho, A. \& Threlfall, W.R. (1989) The effects of oestrus cow serum on the in vitro maturation and fertilization of the bovine follicular oocytes. Theriogenology 31, 693-699.

Tervit, H.R. \& Rowson, L.E.A. (1974) Birth of lambs after culture of sheep ova in vitro for up to 6 days. $J$. Reprod. Fert. 38, 177-179.

Tervit, H.R., Whittingham, D.G. \& Rowson, L.E.A. (1972) Successful culture in vitro of sheep and cattle ova. J. Reprod. Fert. 30, 493-497.

Thompson, J.G.E., Simpson, A.C., Pugh, P.A., Donnelly, P.E. \& Tervit, H.R. (1990) Effect of oxygen concentration on in-vitro development of preimplantation sheep and cattle embryos. J. Reprod. Fert. 89, 573-578.

Ushijima, M., Okuda, T., Nakayama, A., Moji, K., Ishida, K., Murata, H., Iguchi, A. \& Etoh, T. (1988) Relationship between the cell number and qualify of Day-8 bovine blastocysts. Proc. 3rd East. Jpn. Soc. Animl Embryo Trans. No. 9, pp. 37-38. (In Japanese.)

Walker, S.K., Quinn, P., Ashman, R.J., Smith, D.H. \& Seamark, R.F. (1986) Protein supplementation for the culture of one-cell embryos of sheep. Proc. Aust. Soc. Reprod. Biol. 18, 9, Abstr.

Walker, S.K., Seamark, R.F., Quinn, P., Warnes, G.M., Ashman, R.J., Smith, D.K. \& Ancell, P. (1988) Culture of pronuclear embryos of sheep in a simple medium. Proc. Ilth Int. Cong. Anim. Reprod. \& A.I., Dublin 4, 483.

Wang, W.L., Jiang, H.S., Lu, K.H. \& Gordon, I. (1990) Effect of condition medium and glucose concentration on the in vitro development of early bovine embryos. Theriogenology 33, 343.

Wright, R.W., Jr \& O'Fallon, J. (1987) Growth of domesticated animal embryos in vitro. In The Mammalian Preimplantation Embryo, pp. 251-271. Ed. B. D. Bavister. Plenum Press, New York.

Yoshida, M. (1987) In vitro fertilization of pig oocytes matured in vivo. Jpn. J. Vet. Sci. 49, 711-718.

Received 26 July 1990 